\title{
Chimney Implosion-A Case Study
}

\author{
Ajay Kumar Jha \\ Central Mine Planning and Design Institute, Coal India Limited, Ranchi 834008, India
}

\begin{abstract}
Chimney implosion is the strategic planning of explosives and accessories materials and timings of its detonation so that chimney collapses on itself, minimising the physical damage to its immediate surroundings. Built in 1885, the brick chimney at kankanee colliery, Sijua area, BCCL (Bharat Collieries Company Limited) was demolished by felling method using the commercial explosives by adopting single-folding and toppling method. The chimney was $31.5 \mathrm{~m}$ in height and suffered structural weaknesses due to progressive deterioration over age, weathering and non maintenance. The chimney was posing potential threat to the safety of the nearby dwellings and surface structures, viz. main mechanical ventilator of Kankanee colliery, $11 \mathrm{KV}$ electrical substation supplying power to Sijua area, BCCL, high tension cable line and busy Katras-Sijua-Dhanbad Dobari Road all falling within a radius of $30 \mathrm{~m}$. About $75.22 \mathrm{~kg}$ of commercial explosive, $100 \mathrm{~m}$ of detonating fuse along with 0 and 25 ms delay detonators were used for controlled demolition of chimney. The chimney got demolished by vertically cascading on its own base without causing any damage to the nearby dwellings and surface structures.
\end{abstract}

Key words: Implosion, chimney demolition.

\section{Introduction}

A few decades back, coal fired boilers were one of the most popular sources of power for operating the steam engine for man and material winding in underground mines. This necessitated construction of tall chimneys made from stone, bricks, concrete, etc.. With the technological advancement and progressive increase in use of electricity, steam engines have been replaced by electric motors and chimneys turning as abandoned structure surrounded by dwellings, important mining installations and surface structures.

The abandoned chimney of Kankanee colliery, Sijua area, BCCL (Bharat Collieries Company Limited) was posing a serious threat to the safety of the nearby dwellings and surface structures due to its progressive deterioration arising out of structural weaknesses due to age, weathering and poor maintenance. The chimney was surrounded by thickly populated dwellings and No. of important structures viz. fan house, $11 \mathrm{KV}$ electrical substation supplying power to Sijua area, BCCL, high tension cable line

Corresponding author: Ajay Kumar Jha, senior manager, research field: rock blasting in mines and construction. E-mail: ajayk_jha_in@yahoo.com. and busy Katras-Sijua-Dhanbad Dobari Road falling within a radius of $30 \mathrm{~m}$. The abandoned chimney was demolished by using controlled implosion technique by toppling the chimney in a pre-determined direction free from structures.

It may kindly be noted that the chimney was in dilapidated condition due to aging problem. It was built in 1885 for a limited life of 30 years. The chimney was facing safety concerns due to poor quality of construction. The district administration did not give administrative permission to capture regular and coloured photograph as Chimney was lying in politically sensitive mining area with population density. However, we captured black and white photographs using our conventional mobile phone having low resolution camera.

The controlled demolition technique using explosives has cost and time advantages with due regard to safety as compared to manual method. This paper describes a case study of demolition of an abandoned chimney near Kankanee Colliery, Sijua Area, and BCCL by felling method using the commercial explosives by adopting single-folding and toppling method. The explosive demolition of 
chimneys and structures are used extensively in Korea [1].

\section{Materials and Methods}

\subsection{Description of the Chimney}

The height of the chimney was $31.5 \mathrm{~m}$ from the base. The inner diameter of the flue passage was $1.24 \mathrm{~m}$ throughout the height of the chimney and outer diameter was $3.0 \mathrm{~m}$. The base of the chimney was standing on four supporting walls of $4.35 \mathrm{~m}$ length, $2.13 \mathrm{~m}$ height and $1.6 \mathrm{~m}$ thick and is shown in Fig. 1. One of the supporting walls had become weak due to weathering thereby causing the chimney to lean on one side and making it a potential source of danger to the nearby dwellings and the surface structures.

Fig. 2 shows the site plan of the chimney describing the nearby surface structures falling within a radius of $30 \mathrm{~m}$.

\section{Results and Discussion}

\subsection{Blast Design in Demolition Process}

In order to effectively disintegrate the chimney, demolition blasting technique was applied to destroy the stability of the structure by applying pre-weakening concept so that the chimney fells under its gravity and breaks up [2, 3]. As the height of the chimney was not very high, multi-folding and toppling technique was not applied and gravity assisted felling method was selected by adopting single folding and toppling technique [4-6]. The toppling of the structure above blasting cut consists of initial destabilization, moved disintegration, collapsing and blasted debris falling on its base [7].

\subsection{Pre Weakening}

A slit of $1.4 \mathrm{~m}$ wide was cut on one side manually to pre-weaken the chimney as shown in Fig. 3 [8]. The $1.4 \mathrm{~m}$ slit size was technically arrived by carrying out the structural analysis using software to determine the extent of weakening created in chimney in advance. It was observed that $1.4 \mathrm{~m}$ slit was sufficient to topple the chimney under its gravity and gravitational moment.

\subsection{Drilling System}

Holes were drilled with compressed air Wagon drill of $100 \mathrm{~mm}$ diameter. A total of 25 Nos. inclined holes

Chimney

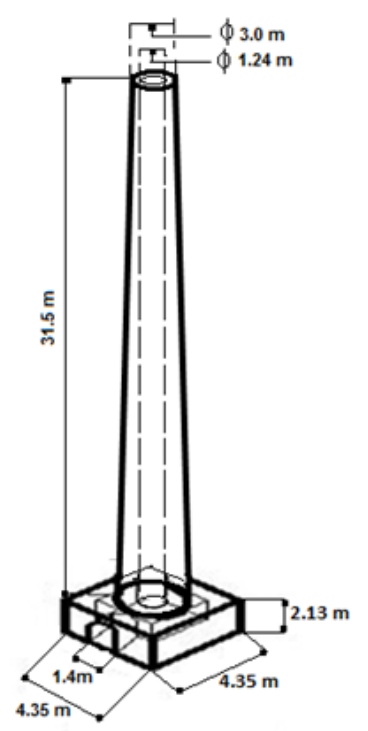

Isometric view

Fig. 1 Isometric view of chimney. 


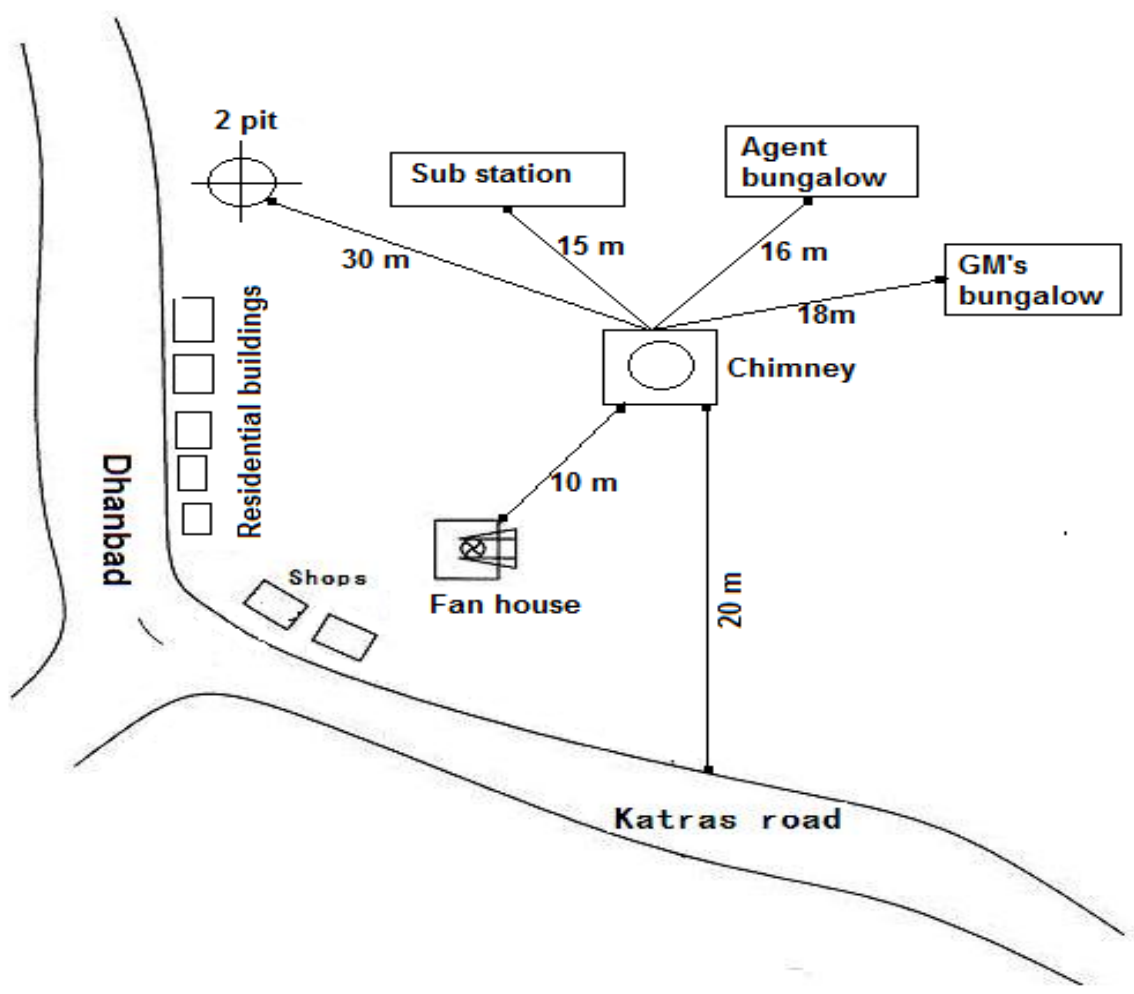

Fig. 2 Site plan of the chimney.

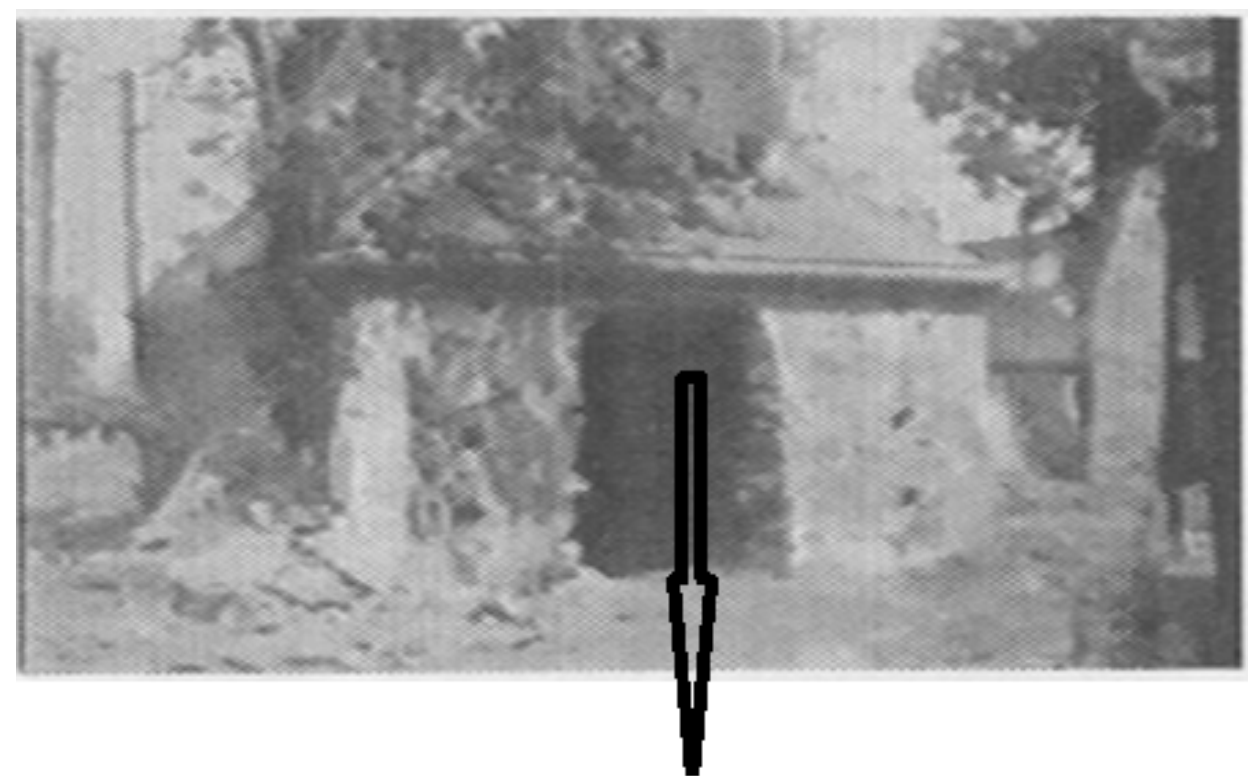

Slit cut by pre-weakening

Fig. 3 Photograph showing slit of $1.4 \mathrm{~m}$ wide in chimney.

of various inclined lengths were drilled at angles varying from $10^{\circ}-45^{\circ}$ from the horizontal pointing towards base of the chimney. The depth of the blast holes were designed considering the thickness of the wall of the chimney to prevent any blown through shots. The positions of holes are shown in Fig. 4. No holes were drilled on that side of supporting brick wall which was structurally weak due to progressive deterioration. 


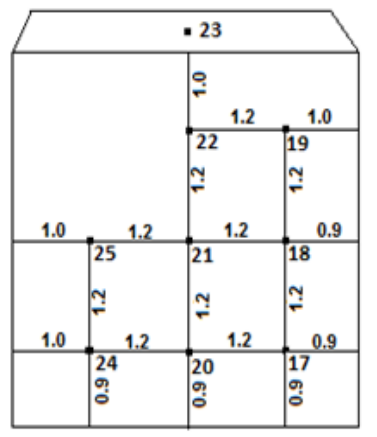

LEFT SECTION

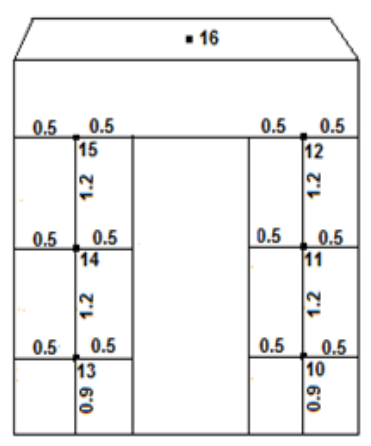

FRONT SECTION

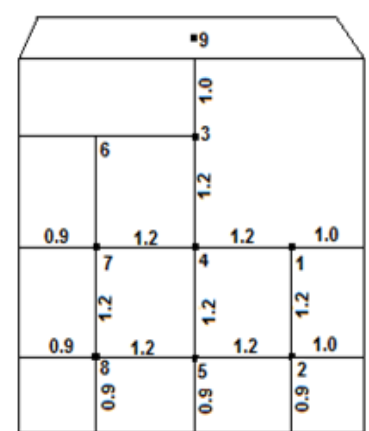

RIGHT SECTION

Not to scale

All dimension are in meters

Fig. 4 Drilling pattern for chimney demolition.

\subsection{Charging System}

Slurry cap sensitive cartridge of $83 \mathrm{~mm}$ dia (2.78 Kg by weight) and cast booster of 100 gms were selected due to its higher weight strength, velocity of detonation and detonation pressure. During calculation of explosive charge, due consideration was given to slight overcharge instead of being under charged to ensure complete demolition instead of part demolition or mere unstabilising the chimney thereby creating a more unsafe condition. Charge quantity in the bottom holes were more compared to the holes at the top for complete smashing the base of the brick chimney. A total of $75.22 \mathrm{~kg}$ of explosives was used for demolition the chimney. The summarised details of drilling and explosive consumption have been shown in Table 1.

\subsection{Initiation System}

The initiation system practiced in demolition of the chimney is shown in Fig. 5. The initiation of blast hole Nos. 1-5, 20-22, 24 and 25 were made with detonating fuse with a delay timing of $25 \mathrm{~ms}$ and blast hole Nos. 6 to 19 and No. 23 were made with detonating fuse with zero short delay detonators. The initiation system helped the explosive force to act from the centre to the periphery thereby releasing the interlocking of bricks from inside and allowing the top to come down on its own weight and to occupy the vacant flue passages with minimum spillage. Clay cartridges mixed with sand were used as a stemming material and were well tamped.

\subsection{Safety Measures/Protection}

Sufficient Nos. of sand bags were stacked up to the height of the charged holes around the chimney so as to prevent the flying fragments during demolition blasting. The additional safety measures taken before carrying out the demolition blasting of chimney is enumerated below:

(1) All High tension lines, electrical fittings, etc. were removed from the vicinity of the chimney.

(2) Supply water pipelines to the adjoining residential buildings were dismantled.

(3) All important installations viz. fan house, substation, pumps, etc. were protected by barricading with adequate sand bags, and wire nets so as to safe guard them from damage due to flying projectiles 
Table 1 Summarised details of drilling and consumption of explosives \& accessories in chimney demolition.

\begin{tabular}{|c|c|c|c|c|c|c|c|}
\hline \multirow[b]{2}{*}{ Hole No. } & \multirow{2}{*}{$\begin{array}{l}\text { Length of hole } \\
\text { (m) }\end{array}$} & \multirow{2}{*}{$\begin{array}{l}\text { Dia. of hole } \\
\text { (mm) }\end{array}$} & \multicolumn{2}{|c|}{ Explosive consumption (kg) } & \multirow[b]{2}{*}{ Total charge (kg) } & \multirow[b]{2}{*}{ Delay (ms) } & \multirow[t]{2}{*}{ Detonating fuse (m) } \\
\hline & & & $\begin{array}{l}\text { Booster } \\
\text { cartridge }\end{array}$ & $\begin{array}{l}\text { Cast } \\
\text { booster }\end{array}$ & & & \\
\hline 6 & 0.85 & 100 & 2.78 & 0.3 & 3.08 & 0 & \\
\hline 7 & 0.82 & 100 & 2.78 & 0.4 & 3.18 & 0 & \\
\hline 8 & 0.82 & 100 & 2.78 & 0.4 & 3.18 & 0 & \\
\hline 9 & 0.81 & 100 & 1.39 & 0.1 & 1.49 & 0 & \\
\hline 10 & 0.86 & 100 & 2.78 & 0.4 & 3.18 & 0 & \\
\hline 11 & 1.05 & 100 & 2.78 & 0.4 & 3.18 & 0 & \\
\hline 12 & 0.69 & 100 & 2.78 & 0.3 & 3.08 & 0 & \\
\hline 13 & 0.95 & 100 & 2.78 & 0.4 & 3.18 & 0 & \\
\hline 14 & 0.93 & 100 & 2.78 & 0.4 & 3.18 & 0 & \\
\hline 15 & 1.00 & 100 & 2.78 & 0.3 & 3.08 & 0 & \\
\hline 16 & 0.86 & 100 & 2.78 & 0.1 & 2.88 & 0 & \\
\hline 17 & 0.52 & 100 & 2.78 & 0.4 & 3.18 & 0 & 100.00 \\
\hline 18 & 0.67 & 100 & 2.78 & 0.4 & 3.18 & 0 & \\
\hline 19 & 0.67 & 100 & 2.78 & 0.3 & 3.08 & 0 & \\
\hline 23 & 0.82 & 100 & 1.39 & 0.1 & 1.49 & 0 & \\
\hline 1 & 0.87 & 100 & 2.78 & 0.4 & 3.18 & 25 & \\
\hline 2 & 0.93 & 100 & 2.78 & 0.4 & 3.18 & 25 & \\
\hline 3 & 0.84 & 100 & 2.78 & 0.3 & 3.08 & 25 & \\
\hline 4 & 0.81 & 100 & 2.78 & 0.4 & 3.18 & 25 & \\
\hline 5 & 0.90 & 100 & 2.78 & 0.4 & 3.18 & 25 & \\
\hline 20 & 0.93 & 100 & 2.78 & 0.4 & 3.18 & 25 & \\
\hline 21 & 0.92 & 100 & 2.78 & 0.4 & 3.18 & 25 & \\
\hline 22 & 0.83 & 100 & 2.78 & 0.3 & 3.08 & 25 & \\
\hline 24 & 0.91 & 100 & 2.78 & 0.4 & 3.18 & 25 & \\
\hline 25 & 0.88 & 100 & 2.78 & 0.4 & 3.18 & 25 & \\
\hline
\end{tabular}

Total charge: $75.22 \mathrm{Kg}$.

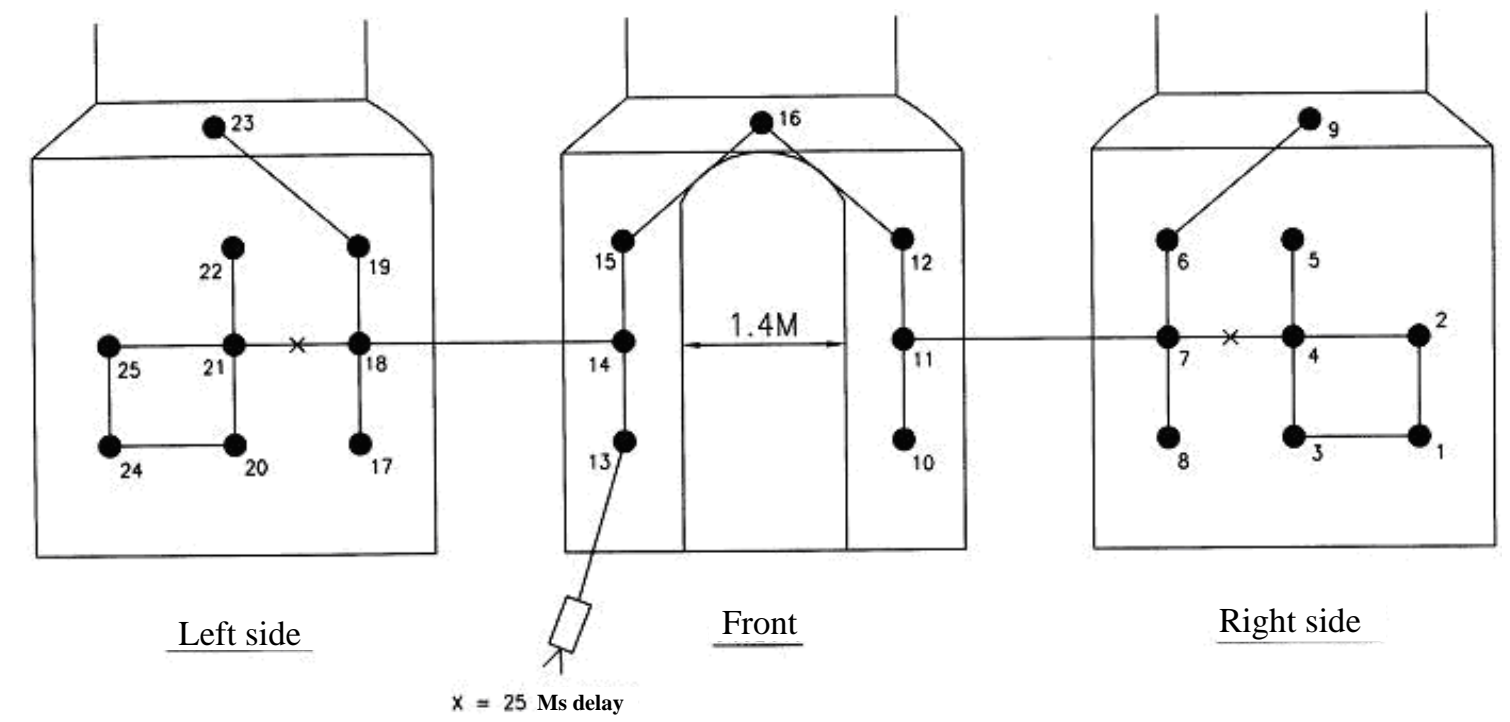

Not to scale

Fig. 5 Initiation pattern for chimney demolition. 
resulting from vertical demolition.

(4) All nearby inhabitants were taken to a safe place at the time of blasting.

(5) The traffic on both sides of the DB Road was blocked during blasting.

(6) Sufficient No. of guards was posted with walkie-talkie, signalling hooters so as to prevent any inadvertent entry during blasting time.

\subsection{Demolition}

The chimney cascaded vertically down on its own base and the debris heaped around its own base. The movement of the chimney structure was captured by camera and is shown in Figs. 6-8, respectively. There was no fly rock generation and damage to any nearby surface structure.

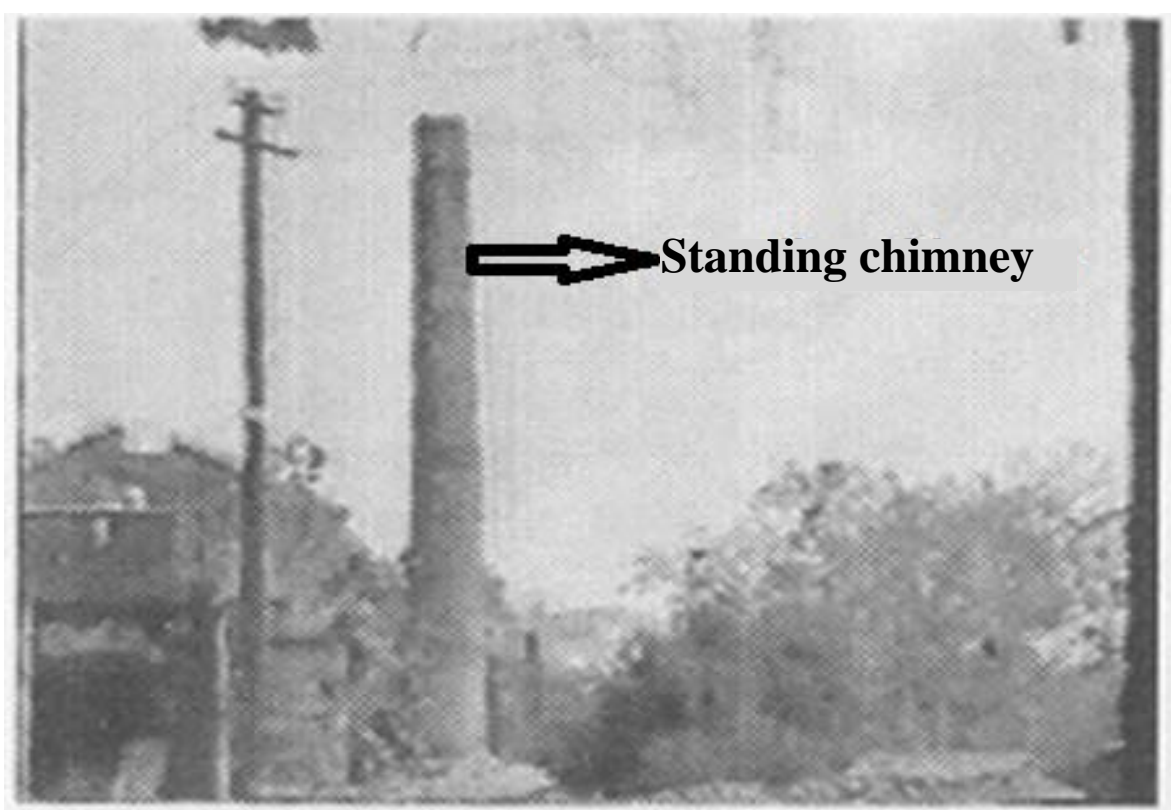

Fig. 6 Photograph showing the chimney before the demolition blasting.

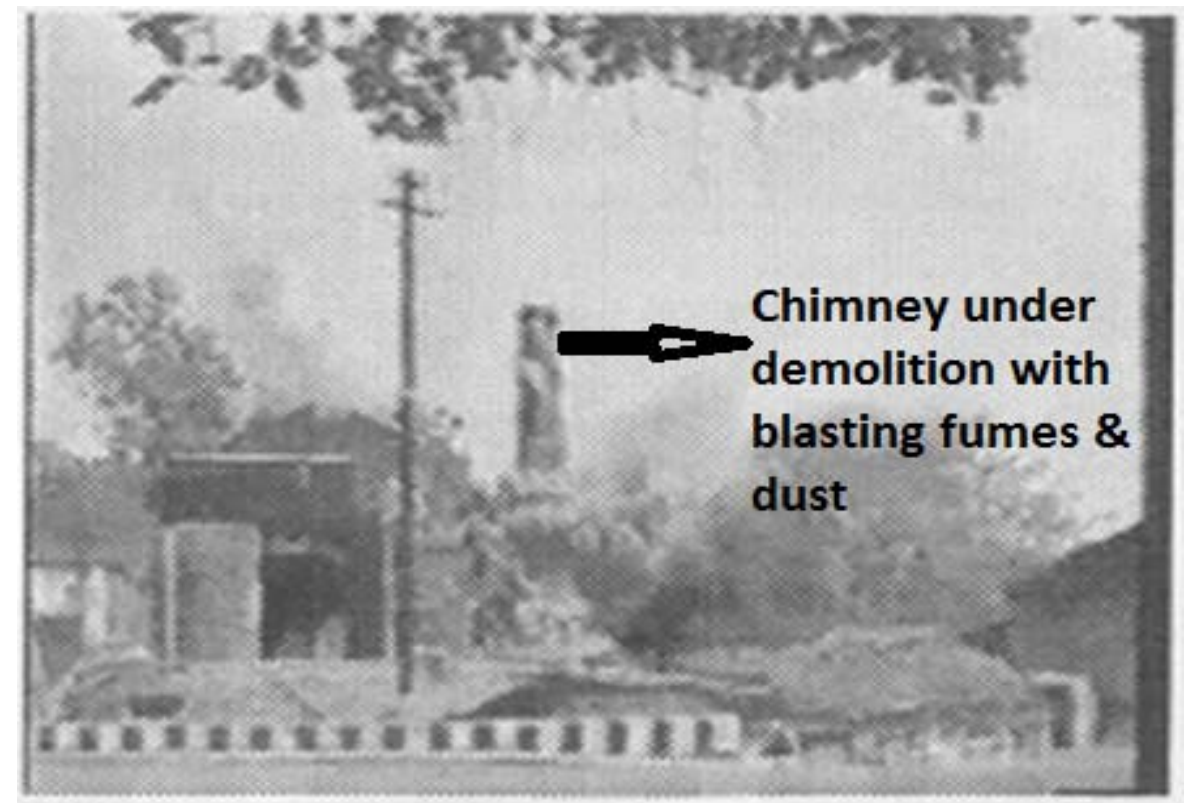

Fig. 7 Photograph showing the chimney falling under gravity during demolition blasting. 


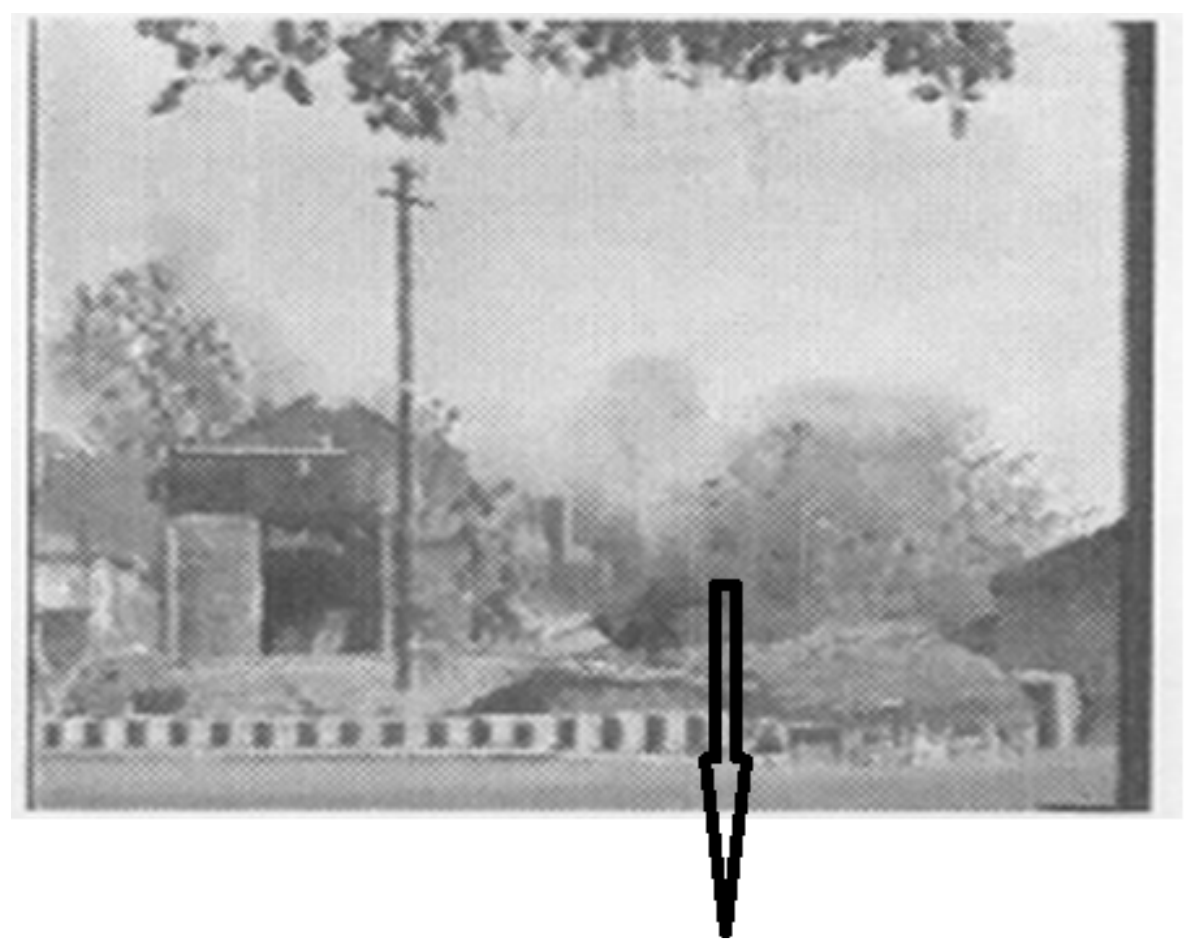

Debris of chimney with blasting dust and fumes

\section{Fig. 8 Photograph showing the debris of demolished chimney.}

\section{Conclusions}

The $31.5 \mathrm{~m}$ old brick chimney was demolished successfully by the felling method using commercial explosives. This case provided a good example for successful application of commercial explosives in demolition of old chimneys with due regard to safety.

\section{Acknowledgement}

The authors express the special gratitude to the management and the work persons of the Kankanee colliery, Sijua Area, BCCL for their whole hearted involvement and co-operation during demolition work. The authors are also thankful to the local district authority, district police officials and medical team for rendering all necessary help while conducting the demolition work.

\section{References}

[1] M.S. Ahn, Case study of blasting demolition of building structure and future development prospect, Youngnam Branch of Korean Society of Explosives and Blasting Engineering, Korea, 2002, pp. 95-102.

[2] W. Hao, The controlled blasting demolition of a sizteen story building in complex surroundings, Engineering Blasting (4) (1999) 30-35.

[3] L.D. zhong, Application Manual of Engineering Blasting, Metallurgical Industry Publishing House, Beijing, 1996.

[4] B.X. Zheng, X.L. Wei, Explosive demolition of a nitric acid tower in Korea, in: Proceedings of the Asian-Pacific Symposium on Blasting Techniques, Beijing, China, 2007, pp. 326-332.

[5] H.D. Min, Y.J. Lee, Y.S. Song, Explosive demolition of a nitric acid tower in Korea, in: Proceedings of the Asian-Pacific Symposium on Blasting Techniques, Beijing, China, 2007, pp. 289-294.

[6] J.H. Zhou, Determination of vibration safety distance in blasting demolition of buildings, Blasting Supplement (1993) 165-169.

[7] S.Y. Feng, City control blasting, Chinese Railway Publisher, Beijing, 1985, pp. 13-17.

[8] A.K. Jha, D. Basu, Explosives and blasting, in: Proceedings of the 34th ICSMRI, New Delhi, India, 2011, pp. 437-443. 